\section{Landscape-style Maps in Traditional Chinese Local Government}

\author{
OSAWA Akihiro ${ }^{\mathrm{a}, *}$ \\ ${ }^{a}$ Gakushuin Universuty, email : 19991252@gakushuin.ac.jp \\ * Corresponding author
}

Keywords: Landscape-style maps, Jiangxi yudi tushuo, Annotated maps

\section{Abstract:}

\section{1}

The various landscape-style maps that we have recently been learning about were originally painted at Local government offices. It is thought that they were not made for printing and publication but were kept as government materials.

This becomes clear by looking at the Daming Yitongzhi 大明一統志 and various regional gazetteers, but the focus of traditional Chinese gazetteers was chronology: which individuals came from that area (like a family's ancestors), who was appointed to that location, or whether any literary works are associated with the place. In other words, the importance of geographic texts in traditional China lay in exploring a location's past and recognizing that area and its people.

On the other hand, maps placing importance on practical utility were also drawn to meet actual political and military demands. The annotated maps compiled by government offices in the late Ming recorded the actual state of affairs from the vantage point of administrative needs.

This change, which attached importance to local realities, became quite pronounced from the Wanli 萬暦 era onwards and can be confirmed on the basis of extant atlases and annotated maps from local government offices. An early example indicative of this trend is the Linghai $y u t u$ 嶺海輿圖 by Yao Yu 姚䖒, which is included in the Siku quanshu 四庫全書 and is judged to be valuable for providing detailed information about contemporary affairs and defences and for having established a different format for local gazetteers. ${ }^{\text {i) }}$ It is said to have been compiled when Yao Yu was regional inspector (xun'an $y u s h i$ 巡按御史) of Guangdong and to have a preface by Zhan Ruoshui 湛若水 dated Jiajing 嘉靖 21 (1542). One reason that various maps from around the country, including annotated maps, have survived may be that a need for them came to be widely felt in government offices.

2

It used to be extremely rare to see the originals of maps created by late-Ming regional government offices. Subsequently, photographic reproductions of the Nanjing fuxian ditu ce 南京府縣地圖冊 in the Zhenjiang 鈚江 Museum, the Jiangxi quansheng tushuo 江西全省圖説 (江西輿地圖説) [Map of Jiangxi Province with Explanations] in the National Library of China, and other provincial maps and explanatory descriptions made using traditional techniques of the Ming and Qing periods have been included in collections like Cao Wanru曹婉 如, et al. (eds.), Zhongguo gudai ditu ji: Ming dai 中國古 代地圖集 : 明代 [Collection of Chinese Old Maps: The Ming Period] (Wenwu Press, 1994) and Zhonghua gu ditu zhenpin xuanji 中華古地圖珍品選集 [Collection of Rare Chinese Old Maps] (Ha'erbin ditu Press, 1998).

The reason for the attention paid to this early-Wanliperiod Jiangxi yudi tushuo 江西輿地圖説 is partially because it is thought to be one of the earliest paintings by a government office, but it is also because of the existence of Zhao Bingzhong 趙秉忠's Jiangxi yudi tushuo (Jilu huibian 紀録彙編, fasc. 208) and Wang Shimao 王世禁's Rao Nan Jiu sanfu tushuo 饒南九三府 圖説(Jilu huibian, fasc. 209), works from the same period that can be contrasted with this map book.

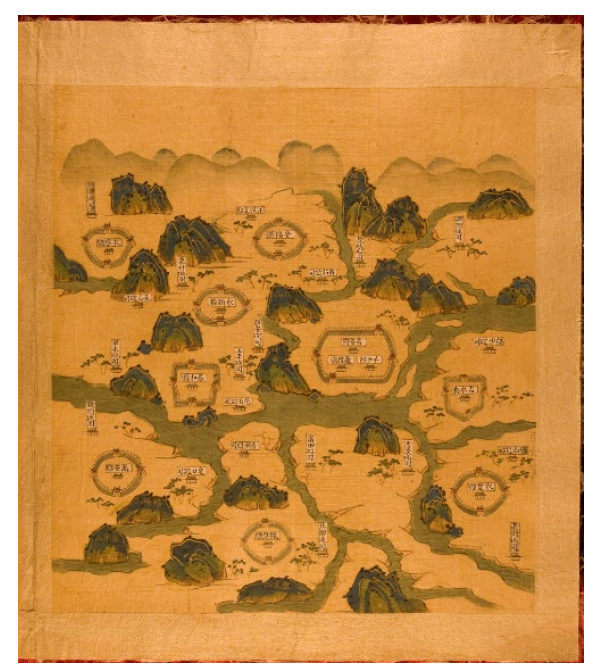

Figure 1. “Map of Ji'an prefecture 吉安府圖” Map of Jiangxi Province with Explanations, World Digital Library

I have discussed this in detail elsewhere, but we have confirmed, from photographs of picture map and explanatory descriptions of Taihe 泰和 County contained in the Zhonghua gu ditu zhenpin xuanji, that the original early-Wanli -period Jiangxi yudi tushuo is extant in the collection of the National Library of China in Beijing, making it possible to investigate the specifics of government-office illustrations. It also became clear that the textual contents of the Jiangxi yudi tushuo (held by the National Library of China in Beijing) and the Jilu huibian version are nearly identical. ${ }^{\text {ii) }}$ 
According to Wang Shimao's "Sanjun ditu shuo ba 三郡地圖説跋” in the Jilu huibian, these explanatory descriptions were compiled by the censors after the picture maps of administrative divisions' borders had been painted; explanations had been added; and an investigation had been made of each area's complexity 繁 簡, importance 衝僻, and lawlessness 難易.

We only have a small number of examples, but these map and explanatory descriptions clarify the actual circumstances of the regions from a different perspective than that of local gazetteers. They contain forthright descriptions of the current situation, such overpopulation on barren land, there being many lawsuits, or the difficulties caused by flood damages.

Unlike local gazetteers, the Jiangxi yudi tushuo records the bureaucratic evaluations of "importantunimportant and complex-simple 衝僻繁簡”, suggesting an awareness of directly dealing with administrative necessities. In the depictions of prefectures and counties, distant mountains are hazy, while the rest of the landscape is shown in the manner of the "blue-and-green" style of landscape painting 青綠山水畫, and the names of the mountains are indicated in gold paint. Buildings are indicated with ink inside white squares, but they are mostly public facilities.

\section{4}

Moreover, exhibition catalogues from the National Palace Museum in Taipei contain a variety of landscapestyle maps created by government offices since the early Ming, including the early-Ming Jiangnan ge daofu tubiao 江南各道府圖表. Additionally, the Library of Congress in the US holds the Yangzhou fu tushuo 揚州府圖説 and the Quanzhou fu yudi tushuo 泉州府輿地圖説. The National Library of France (BnF) holds the Ming Huai'an fu tushuo 淮安府圖説, which has also been made available on Gallica. The Guimet Museum Library likewise holds the Qing Jiangsu Anhui liang sheng de 74 fu zhou xian tu (tentative title) 江蘇安徽兩省的 74 府州 縣圖（擬題）.

A variety of such picture maps were made at the local government offices. For example, the Guimet Museum Library also holds a good collection of landscape-style maps in late-Qing. Moreover, Hua Linfu 華林甫, Li Cheng 李誠, and Zhou Lei 周否, Deguo Pulushi wenhua yichan tushuguan zang wan Qing Zhili Shangdong xiangji yutu zhengli yu yanjiu 德國普魯士文 化遺産圖書館蔵晚清直隷山東縣級興圖整理与研究 [Organizing and Researching Late-Qing Maps from Zhili and Shandong Held by the German Prussian Cultural Heritage Library]) (Qilu shushe, 2015) introduce maps that existed in the local government offices in Zhili 直隷 and Shandong 山東 province toward the end of the Qing period.

The fact that the Jiangxi yudi tushuo, compiled at a provincial level, took the form of a landscape painting is probably indicative of the fact that the maps brought together by the Bureau of Operations in the Ministry of
War 兵部職方司 were in the form of landscape paintings. Although the maps found in the Da Ming yitongzhi 大明一統志 and various local gazetteers differ in their relative detail, they may generally be described as landscape-style maps, and this would have been because the maps compiled by government offices at various levels in the bureaucratic hierarchy were originally drawn in the style of landscape paintings.

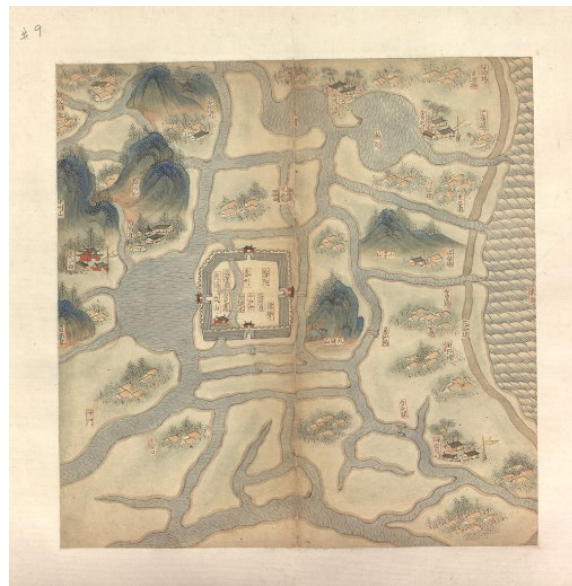

Figure 2. "Map of Taizhou subprefecture 泰州圖” Illustrated Album of Yangzhou Prefecture World Digital Library

5

In other words, the originals of these coloured landscape paintings were produced in the provinces and then gathered together by the central government. It should be possible to trace such maps back to the "Jingde shanchuan xingshi tu” 景德山川形勢圖 (Map of the Geographical Layout of Mountains and Rivers during the Jingde Era) of Jingde 景德 4 (1007) of the Northern Song, when painters were dispatched throughout the country to draw the "topography of mountains and rivers and geographical distances” (Yuhai 玉海 fasc.14).

In a sense, these landscape-style maps can be seen as attempts in Chinese history to depict the $q i$ 気 of the universe and mountains and rivers. So they had a long life span in the history of traditional Chinese maps.

i) Siku quanshu zongmu 四庫全書総目, “Shibu” 史部 24, “Dili lei” 地理類 1, Linghai yutu 嶺海輿圖, 1 fasc. (held by family of Zheng Dajie 鄭大節 in Zhejiang).

ii) Osawa Akihiro, "Cartography in Late Ming Period: Each Linage of Governmental Maps and Panoramic Maps" (Language, Culture and Society 8, 2010). [in Japanese] 